\title{
References:
}

1. Rickman, J. C., Bruhn, C. M., \& Barrett, D. M. (2007). Nutritional comparison of fresh, frozen, and canned fruits and vegetables II. Vitamin A and carotenoids, vitamin E, minerals and fiber. Journal of the Science of Food and Agriculture, 87(7), 1185-1196.

2. Walkling-Ribeiro, M., Noci, F., Cronin, D. A., Lyng, J. G., \& Morgan, D. J. (2010). Shelf life and sensory attributes of a fruit smoothie-type beverage processed with moderate heat and pulsed electric fields. LWT - Food Science and Technology, 43(7), 1067-1073.

3. Barbosa-Canovas, G. V., Altunakar, B., \& Mejia-Lorio, D. J. (2015). Freezing of Fruits and Vegetables: An Agribusiness Alternative for Rural and Semi-Rural Areas. Chapter 1. Food and Agriculture Organization of the United Nations. Rome.

4. Zhang, Y., Zhao, J.-H., Ding, Y., Xiao, H.-W., Sablani, S. S., Nie, Y. et. al. (2018). Changes in the vitamin $\mathrm{C}$ content of mango with water state and ice crystals under state/phase transitions during frozen storage. Journal of Food Engineering, 222, 49-53.

5. Odarchenko, D., Odarchenko, A., Sokolova, E., \& Mikhailik, V. (2018). Investigation of the influence of the process of freezing on microbiological factors of safety of frozen semi-product for cooking drink smoothie. EUREKA: Life Sciences, 2, 62-67.

6. Odarchenko, D., Odarchenko, A., Sokolova, E., \& Mikhailik, V. (2018). Cryoscopic and microbiological study of the semi-finished product for making a smoothie drink. Eastern-European Journal of Enterprise Technologies», seriya: Technology and equipment of food production, 2, $11(92), 65-70$.

\section{NECESSITY OF FILTRATION IN LIQUEUR-VODKAS PRODUCTION}

\section{Lesia Tarasiuk ${ }^{1}$ \\ Svitlana Oliynyk ${ }^{2}$}

DOI: https://doi.org/10.30525/978-9934-588-11-2_16

The constant development of the market requires the production of more qualitative alcoholic beverages with an increased resistance. Taking this requirement into account producers are looking for methods and means to improve the technology of production. Organoleptic parameters are the most important characteristics of the liqueur-vodkas products quality. While tasting study of products quality it is estimated appearance, taste and aroma, but of the most importance is beverage's transparency [1, p. 356].

For the filtration of alcohol-water mixtures and prepared products there are used such materials as quartz sand, garnet, mountain crystal, hydro-anthracite as well as some variants of linen, cotton, felt canvas, hushcloth, etc. [2, p. 6].

When creating recipes there are used such ingredients as skimmed milk powder, quail and chicken egg white, etc., which are coagulating substances that help to improve the organoleptic characteristics of sorting [2, p. 4].

\footnotetext{
${ }^{1}$ National University of Food Technology, Ukraine

${ }^{2}$ National University of Food Technology, Ukraine 
In the current «Master formula for the production of vodkas and alcoholic beverages», the filtration stages and their technological parameters are regulated; these are temperature, pressure, speed during the main filtration cycle, during regeneration, etc.

At the liqueur-vodkas enterprise, it is necessary to filter the following main components or semi-finished products:

- rectified ethyl alcohol at the time of acceptance from transport tanks or alcohol cellar;

- compressor air for blending mixtures and automation of pneumatic systems for removing mechanical impurities, moisture and oil aerosols from it;

- sorting before a coal column to prevent the ingress of mechanical and colloidal impurities on the surface of activated carbon;

- $\quad$ sorting after the coal column to remove particles of activated carbon;

- $\quad$ sorting after additional treatments on machines with special adsorbents;

- $\quad$ sorting after treatment with dry skimmed milk to separate protein suspensions in the production of vodkas;

- ingredients before introduction into a blend product;

- after special treatments of honey water-alcohol mixture and spirit solutions of essential oils, and other opalescent ingredients;

- water or water-alcohol mixture while rinsing bottles before filling or before injection into bottle washing machines;

- clean marriage;

- after preliminary clarification or additional treatments of alcoholized juices and fruit and berry drinks, alcoholic tinctures from vegetable raw materials in the manufacturing of liqueur-vodkas products;

- after removal from fining, clarification or additional treatments of blends of liqueur-vodkas products;

- vodkas and finished blends of liqueur-vodkas products to remove fine suspensions, as well as before bottling;

- ready-made blends of liqueur-vodkas products to increase colloidal stability and resistance to the formation of sediment;

- low-alcoholic beverages for microbiological stabilization;

- water after the preparation of the main filters used to separate colloids, possible microflora of low-alcoholic products and other contaminants.

One of the most popular filtering materials used in the liqueur-vodkas production is quartz sand of size variable fractions [1, p. 355].

Sand filters are used to purify water from mechanical impurities, as well as filtering of mixtures before and after the coal column. Sand filters are easy to use and they are relatively cheap. The disadvantages of using sand filters are:

- $\quad$ significant costs during the preparation of quartz sand;

- migration of microcomponents of quartz sand to the filtrate;

- insufficient level of filtration fineness; 
- instability and possible changes of pressure in the fluid flow, possible leakage of suspensions and other mechanical impurities;

- formation of microchannels in the layers of quartz sand, which can affect the transparency of the filtered product.

Implemented studies of natural silicide have shown that in comparison to quartz sand this natural material has several advantages, such as higher hardness by $20-$ $25 \%$ by Moss, chemical resistance by $30-35 \%$, and homogeneity by $45-50 \%$.

The application of natural silicide as a natural filtering material does not require the use of chemical reagents, including chlorine hydride at the preparation stage, which is positive.

During filtration of water by natural silicide in comparison to quartz sand, the relative volume increases during one filtration cycle:

- prepared water for $200-250$ volumes/volume of material, while improving the transparency and color of the prepared water by $15-30 \%$,

- water-alcohol solution for 350 - 400 volumes/volume of material, and transparency of the water-alcohol mixture by $25-30 \%$.

Based on the carried study, it was established that the use of natural silicide gives an opportunity to increase the transparency of prepared water and mixture; it was shown the perspectivity of usage for filtering at the stages of water preparation and mixture clarification in liqueur-vodkas production.

\section{References:}

1. Ivanov, S., Domaretskyi V., Prybylskyi V. (2012). Innovatsiini tekhnolohii produktiv brodinnia $i$ vynorobstva [Technology innovation of fermentation and winemaking]. Kyiv : NUKhT.

2. Likero-vodochnoe proizvodstvo i vinodelie. (2000). Osvetlenie tekhnolohicheskoi vody metodom mnohosloinoho filtrovaniia [Clarification of process water by multilayer filtration]. Informatsionnyi biulleten Otraslevye vedomosti, (10), 1-12. 